\title{
Spectrophotometric Determination of Salbutamol Sulphate by Coupling with Diazotized 5-Amino-2-chlorobenzotrifluoride - Application to Pharmaceutical Preparations
}

\author{
Nabeel S. Othman \\ Ali M. Asaad \\ Department of Chemistry/College of Science/ University of Mosul
}

(Received 18/6/2013;Accepted $18 / 8$ / 2013 )

\begin{abstract}
A simple, rapid and sensitive spectrophotometic method for the estimation of trace amounts of salbutamol sulphate (SBS) in pharmaceutical preparations has been proposed .The method is based on the coupling reaction of the intended compound with diazotized 5-amino-2chlorobenzotrifluoride in alkaline medium and in the presence of Triton X-100 to form a yelloworange dye that shows maximum absorption at $467 \mathrm{~nm}$. Beer's law is obeyed over the range $5-300$ $\mu \mathrm{g} / 10 \mathrm{ml}$ (i.e.,0.5-30 ppm) with a molar absorptivity of $4.20 \times 10^{4} 1 . \mathrm{mol}^{-1} . \mathrm{cm}^{-1}$ and Sandell's sensitivity index of $0.0139 \mu \mathrm{g} . \mathrm{cm}^{-2}$, a relative error of +1.08 to $+3.46 \%$ and a relative standard deviation of \pm 0.76 to $\pm 3.50 \%$, depending on the concentration. The method has been applied to estimate salbutamol sulphate in syrup, tablet and ventolin.
\end{abstract}

Keywords: Salbutamol sulphate, diazotized 5-amino-2-chlorobenzotrifluoride, diazo-coupling, Triton X-100, spectrophotometry

\section{القدير اللمي لكبريتلت السالبيوتامط بالافترلن مع الكالف المؤزت 5 -مينو -2 - كلوروننزو -لالثي فلوربد - ظلبقلت في مستحضرات مصيدلانية}

\section{الملذص}

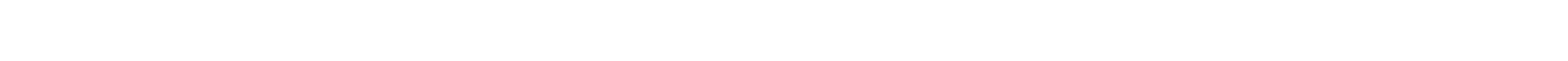

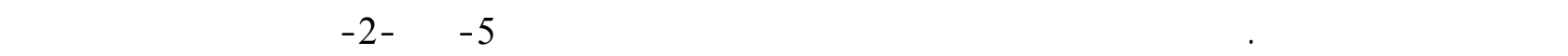

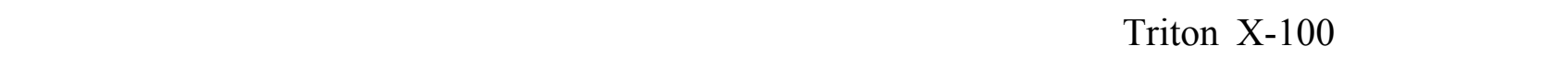

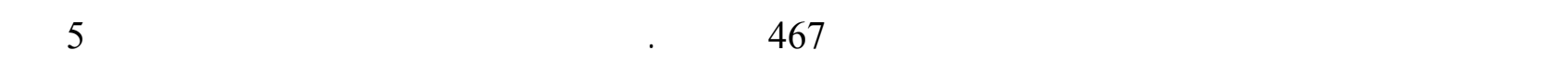

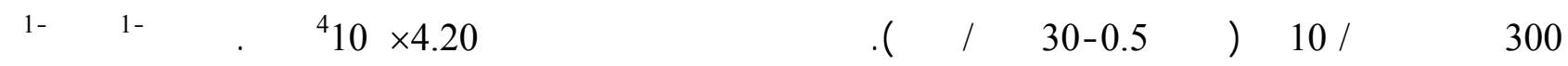

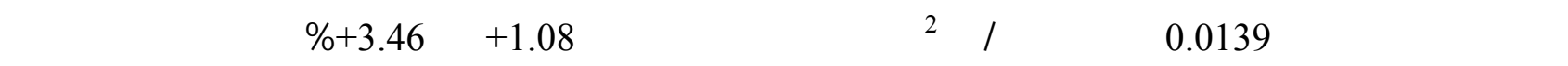
النسب في مدى اللشراب والأقراص والفنتولين.

الهاملت الدالة: كبريتات السالبيوتامول، كاثف5-امينو-2-كلوروبنزوثلاثي الفلوريد المؤزد، الاقتران الازوي، تقنية مطيافية.

\section{INTRODUCTION}

Salbutamol sulphate is the racemic form of salbutamol, it is an important drug, indicated for the relief of severe bronchial spasm associated with asthma (Fattah et al., 1998). Salbutamol 
sulphate is [di[(RS)-2-(1,1-dimethyl) ethylamino-1-[4-hydroxy-3-(hydroxymethyl)phenyl] ethanol] sulphate] a white or almost white, crystalline powder, freely soluble in water, slightly soluble in alcohol and in ether, very slightly soluble in methylene chloride and has the following structure (British Pharmacopoeia, 2007 ).

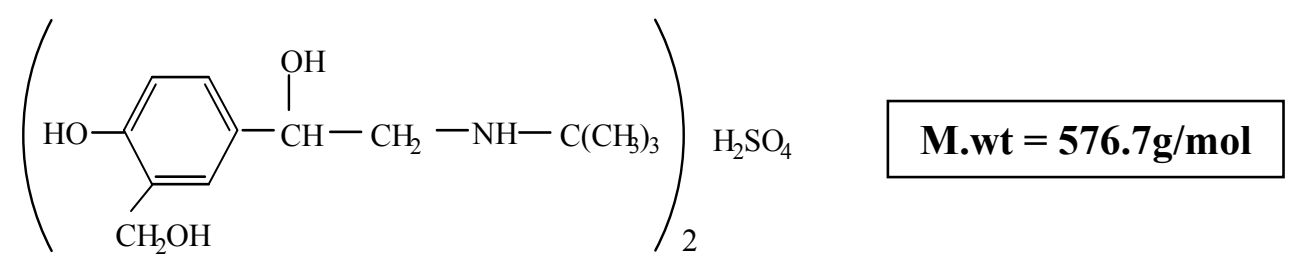

\section{Salbutamol sulphate}

The assay of Salbutamol sulphate officially listed in British Pharmacopoeia describes a potentiometric titration procedure (British Pharmacopoeia, 2007).

Several analytical methods for the determination of salbutamol were developed and reported such as TLC (Dave et al., 2011), GC and GC-MS (Caban et al., 2011; Wang et al., 2010), cyclic voltammetry (Ganjali et al., 2005), adsorptive stripping voltammetry on a carbon paste electrode (Attaran et al., 2012), Capillary electrophoresis coupled with electrochemilumencesis (Bao et al., 2012), flow injection method (Al-Abachi and Subhi, 2013), HPLC and RP-HPLC (Mukesh and Ranjit, 2011; Pai et al., 2009 ; Ghulam et al., 2009 ; Li et al., 2010), HPLC-chemiluminescence (Zhang et al., 2011), solid phase extraction (SPE)-HPLC (Liu and Wang, 2011; Yan et al., 2012), and fluorescence (Tang et al., 2010).

Various spectrophotometric procedures have been reported for the determination of salbutamol sulphate as a pure and in dosage form using different reagents such as diazotized sulphanilic acid (Othman and Zakaria, 2004), diazotized p-nitroaniline (Othman and Hamdoun, 2005), Folinciocalteu (Basavaiah and Prameela, 2003), iron(III) with ferricyanide (Kanakapura and Huiikal, 2003), hydroxyl ammonium chloride in alkaline medium (Manasa, 2013), pphenylenediamine in presence of sodium meta periodate (Al-Hafith, 2005), 2,6dichloroquinonechlorimide and 7,7,8,8-tetracyanoquindimethan (Mohamed et al., 2002), and sodium hydroxide (Eswarudu et al., 2012). The present work describes a spectrophotometric method for the determination of salbutamol sulphate. The method is based on coupling the salbutamol sulphate with diazotized 5-amino-2-chlorobenzotrifluoride to form a stable and soluble azo dye product .

\section{Apparatus:}

\section{THE EXPEREMENTAL}

The spectrophotometric measurements were carried out on Jasco V-630 using $1 \mathrm{~cm}$ glass cells.

\section{Reagents}

All chemicals used are of the highest purity available.

Salbutamol sulphate solution, $100 \mu \mathrm{g} \cdot \mathrm{ml}^{-1}$.

A $0.0100 \mathrm{~g}$ amount of salbutamol sulphate was dissolved in distilled water, then the volume was completed to $100 \mathrm{ml}$ in a volumetric flask with distilled water.

\section{Diazotized 5-amino-2-chlorobenzotrifluoride solution $5 \times 10^{-3} \mathrm{M}$.}

This solution was prepared daily by dissolving $0.0978 \mathrm{~g}$ of 5 -amino-2-chlorobenzotrifluoride in $10 \mathrm{ml}$ of ethanol then a $3.0 \mathrm{ml}$ of concentrated $\mathrm{HCl}$ was added, followed by dilution to $80 \mathrm{ml}$ with distilled water, then the solution was transferred into a $100-\mathrm{ml}$ volumetric flask and cooled to $(0-5)$ ${ }^{\circ} \mathrm{C}$ in an ice-bath, a $0.0345 \mathrm{~g}$ of sodium nitrite was added then stirred vigorously, after 5 minutes the solution was made up to $100 \mathrm{ml}$ with cooled distilled water and stored in a dark bottle. 


\section{Sodium hydroxide solution, $2 \mathrm{M}$.}

This solution was prepared by the dilution of the concentrated volumetric solution (1Ampoule, Fluka) to $500 \mathrm{ml}$ with distilled water and then transferred to a plastic bottle.

Triton X-100, (1\%).

A $1.0 \mathrm{~g}$ of Triton $\mathrm{X}-100$ was dissolved in $100 \mathrm{ml}$ of distilled water.

Interferences solutions, $1000 \mu \mathrm{g} \cdot \mathrm{ml}^{-1}$.

These solutions were prepared by dissolving $0.1 \mathrm{~g}$ of each of them in $100 \mathrm{ml}$ of distilled water.

Butadine syrup solution, $100 \mu \mathrm{g} \cdot \mathrm{ml}^{-1}$.

This solution was prepared by diluting $25 \mathrm{ml}$ of butadine syrup ( $2 \mathrm{mg}$ salbutamol sulphate per 5 $\mathrm{ml})$ to $100 \mathrm{ml}$ with distilled water in a volumetric flask.

\section{Butadin a tablets solution, $100 \mu \mathrm{g} \cdot \mathrm{ml}^{-1}$.}

Finely 5 powdered tablets of butadine drug (each tablet contains $2 \mathrm{mg}$ salbutamol sulphate) were dissolved in $80 \mathrm{ml}$ of distilled water, and the solution was shaked and warmed. The solution was filtered into a 100-ml volumetric flask, the residue was washed with distilled water and diluted to volume with distilled water to obtain $100 \mathrm{mg} / \mathrm{l} \mathrm{salbutamol} \mathrm{sulphate.}$

\section{Solution, $100 \mu \mathrm{g} \cdot \mathrm{ml}^{-1}$.Salb. Vent.}

A $2 \mathrm{ml}$ of salb. vent. (5mg salbutamol sulphate per $1 \mathrm{ml}$ ) diluted to $100 \mathrm{ml}$ with distilled water in a volumetric flask to obtain $100 \mu \mathrm{g} \cdot \mathrm{ml}^{-1}$ salbutamol sulphate solution.

\section{Principles of the method}

\section{RESULTS AND DISCUSSION}

The method included the following steps:

- $\quad$ Preparation of diazotized 5-amino-2-chlorobenzotrifluoride.

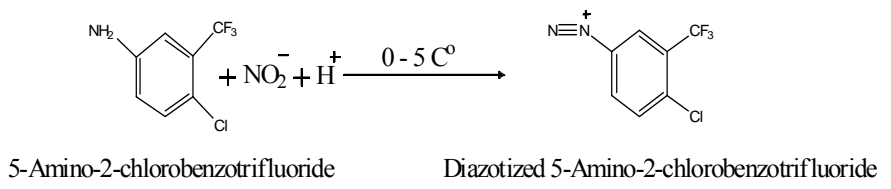

- Coupling of salbutamol sulphate with diazotized 5-amino-2-chlorobenzotrifluoride to form a yellow dye in a basic medium.

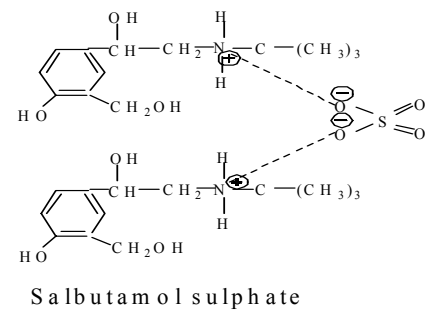

\section{Optimum reaction conditions}
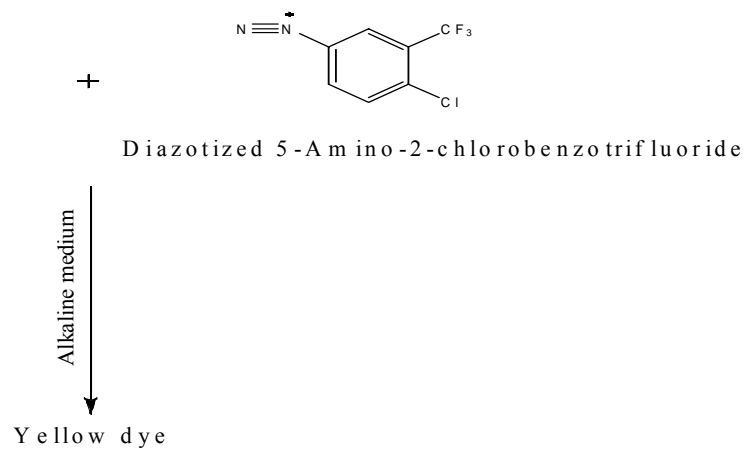

The effect of different factors on the formation of the colored dye is investigated and the reaction conditions have been optimized.

For the subsequent experiments, $100 \mu \mathrm{g}$ of salbutamol sulphate is taken in $10 \mathrm{ml}$ as a final volume and absorbance measurements are achieved directly after dilution with distilled water at $451.5 \mathrm{~nm}$. 


\section{Selection of diazotized reagent}

Some diazotized reagents $\left(1 \mathrm{ml}\right.$ of $\left.5 \times 10^{-3} \mathrm{M}\right)$ have been selected for optimum conditions. The results in Table (1) show that 5-amino-2-chlorobenzotrifluoride gives the highest intensity with high value of color contrast, therefore, it has been selected for the subsequent experiments.

Table 1: Selection of diazotized reagent

\begin{tabular}{|l|c|c|c|}
\hline $\mathbf{1 ~ m l ~ o f ~}\left(\mathbf{5 x 1 0}^{-3} \mathbf{M}\right)$ diazotized reagent & $\boldsymbol{\lambda}_{\max }(\mathbf{n m})$ & $\Delta \boldsymbol{\lambda}_{\max }(\mathbf{n m}) *$ & Absorbance \\
\hline 5-Amino-2-chlorobenzotriflouride & 451.5 & 141.5 & 0.3068 \\
\hline 3-Aminobenzotriflouride & 437 & 138 & 0.2023 \\
\hline
\end{tabular}

- $\Delta \lambda_{\max ,=} \lambda_{\max } \mathrm{S}-\lambda_{\max } \mathrm{B}$ where $\mathrm{S}=$ Sample, $\mathrm{B}=$ Blank

\section{Optimum amount of diazotized 5-amino-2-chlorobenzotriflouride reagent}

The effect of different amounts $(1.0-6.0 \mathrm{ml})$ of 5 -amino-2-chlorobenzotriflouride $\left(5 \times 10^{-3} \mathrm{M}\right)$ reagent on the absorbance of solutions containing different amounts of salbutamol sulphate (50-300 $\mu \mathrm{g} / 10 \mathrm{ml}$ ) has been studied; the results in Table (2) show that $4 \mathrm{ml}$ of diazotized 5-amino-2chlorobenzotriflouride reagent gives highest absorbance and with best determination coefficient $\left(\mathrm{R}^{2}=0.999\right)$, therefore this volume of diazotized reagent was selected for the subsequent experiments.

Table 2: The optimum amount of diazotized reagent

\begin{tabular}{|c|c|c|c|c|c|}
\hline \multirow{2}{*}{$\begin{array}{c}\mathrm{ml} \text { of }\left(5 \times 10^{-3} \mathrm{M}\right) \text { diazotized reagent } \\
\text { solution }\end{array}$} & \multicolumn{4}{|c|}{ Absorbance / $\mu$ g of salbutamol sulphate } & \multirow[t]{2}{*}{$\mathbf{R}^{2}$} \\
\hline & $\mathbf{5 0}$ & 100 & 200 & 300 & \\
\hline 1.0 & 0.1701 & 0.3068 & 0.5642 & 0.6468 & 0.947 \\
\hline 2.0 & 0.1963 & 0.4054 & 0.6835 & 1.0793 & 0.994 \\
\hline 3.0 & 0.2121 & 0.3984 & 0.7602 & 1.3131 & 0.988 \\
\hline 4.0 & 0.2272 & 0.4596 & 0.9413 & 1.3872 & 0.999 \\
\hline 5.0 & 0.2200 & 0.4272 & 0.9258 & 1.3430 & 0.998 \\
\hline
\end{tabular}

\section{Effect of pH}

Salbutamol sulphate undergoes complete diazo-coupling reaction in alkaline medium (Othman and Zakaria , 2004), so that several bases have been tested Table (3) for optimum conditions ( $1 \mathrm{ml}$ of $2 \mathrm{M}$ of each base was added).

Table 3: Selection of base

\begin{tabular}{|c|c|c|c|c|c|}
\hline \multirow{2}{*}{$\begin{array}{c}1 \mathrm{ml} \text { of } \\
\text { Base }(2 \mathrm{M})\end{array}$} & \multirow[t]{2}{*}{$\lambda_{\max (\mathrm{nm})}$} & \multirow{2}{*}{$\Delta \lambda_{\max (\mathrm{nm})}$} & \multicolumn{2}{|c|}{ Absorbance } & \multirow[t]{2}{*}{ Final PH } \\
\hline & & & Sample Vs. Blank & $\begin{array}{l}\text { Blank } \\
\text { Vs.DW. }\end{array}$ & \\
\hline $\mathrm{NaOH}$ & 452 & 143 & 0.4775 & 0.0746 & 12.01 \\
\hline $\mathrm{KOH}$ & 361.5 & 46 & 0.4724 & 0.1877 & 12.23 \\
\hline $\mathrm{NaHCO}_{3}$ & \multicolumn{5}{|c|}{ Turbid } \\
\hline $\mathrm{Na}_{2} \mathrm{CO}_{3}$ & \multicolumn{5}{|c|}{ Turbid } \\
\hline
\end{tabular}

The experimental data in Table (3) showed that the reaction needs a strong alkaline medium and $\mathrm{NaOH}$ gives a highest sensitivity with best color contrast, therefore it has been fixed for the subsequent experiments. 
The optimum amount of sodium hydroxide

The results in Table (4) indicate that $1 \mathrm{ml}$ of $\mathrm{NaOH}(2 \mathrm{M})$ gives the highest intensity of the colored dye and the value of determination coefficient $(0.999)$, therefore this volume has been recommended for the subsequent experiments.

Table 4: The optimum volume of sodium hydroxide

\begin{tabular}{|c|c|c|c|c|c|}
\hline \multirow{2}{*}{$\begin{array}{c}\text { ml of } \\
\text { NaOH (2M) }\end{array}$} & \multicolumn{2}{|c|}{ Absorbance / $\boldsymbol{\mu g}$ of salbutamol sulphate } & Determination coefficient \\
\cline { 2 - 5 } & $\mathbf{5 0}$ & $\mathbf{1 0 0}$ & $\mathbf{2 0 0}$ & $\mathbf{3 0 0}$ & 0.903 \\
\hline 0.5 & 0.0338 & 0.0610 & 0.0882 & 0.2092 & 0.999 \\
\hline 0.8 & 0.2203 & 0.4821 & 1.0587 & 1.5800 & 0.999 \\
\hline 1.0 & 0.2384 & 0.5056 & 1.0518 & 1.5946 & 0.987 \\
\hline 2.0 & 0.2342 & 0.5001 & 0.9011 & 1.1977 & 0.974 \\
\hline 3.0 & 0.2415 & 0.3838 & 0.8325 & 1.0311 & \multicolumn{2}{|c}{} \\
\hline
\end{tabular}

\section{Effect of surfactant}

The effect of several types of surfactants with different orders of addition on color intensity and color contrast of the dye has been investigated. (Table 5 and Fig. 1).

Table 5: The effect of surfactant on dye absorbance

\begin{tabular}{|c|c|c|c|c|c|c|}
\hline \multirow{3}{*}{$\begin{array}{l}\text { Order of } \\
\text { addition }\end{array}$} & \multicolumn{6}{|c|}{ Absorbance/ $1 \mathrm{ml}$ of surfactant solution } \\
\hline & \multicolumn{2}{|c|}{ CTAB $\left(1 \times 10^{-3} M\right)$} & \multicolumn{2}{|c|}{ SDS (1\%) } & \multicolumn{2}{|c|}{ Triton X-100 (1\%) } \\
\hline & Abs. & $\lambda_{\max .(\mathrm{nm})}$ & Abs. & $\lambda_{\text {max.(nm) }}$ & Abs. & $\lambda_{\text {max.(nm) }}$ \\
\hline $\mathbf{I}$ & 0.4563 & 440.5 & 0.5244 & 452 & 0.7033 & 466.5 \\
\hline II & 0.4895 & 441 & 0.6022 & 451.5 & 0.7090 & 467 \\
\hline III & 0.5016 & 438 & 0.5138 & 452.5 & 0.6045 & 467 \\
\hline
\end{tabular}

Note: Absorbance $=0.5259$ without surfactant and $\lambda_{\max .}=451.5 \mathrm{~nm}$

I. $\quad$ Salbutamol sulphate $(\mathrm{S})+\operatorname{surfactant}(\mathrm{C})+$ Reagent $(\mathrm{R})+\mathrm{NaOH}(\mathrm{B})$

II. $\quad \mathrm{S}+\mathrm{R}+\mathrm{C}+\mathrm{B}$

III. $\quad \mathrm{S}+\mathrm{R}+\mathrm{B}+\mathrm{C}$

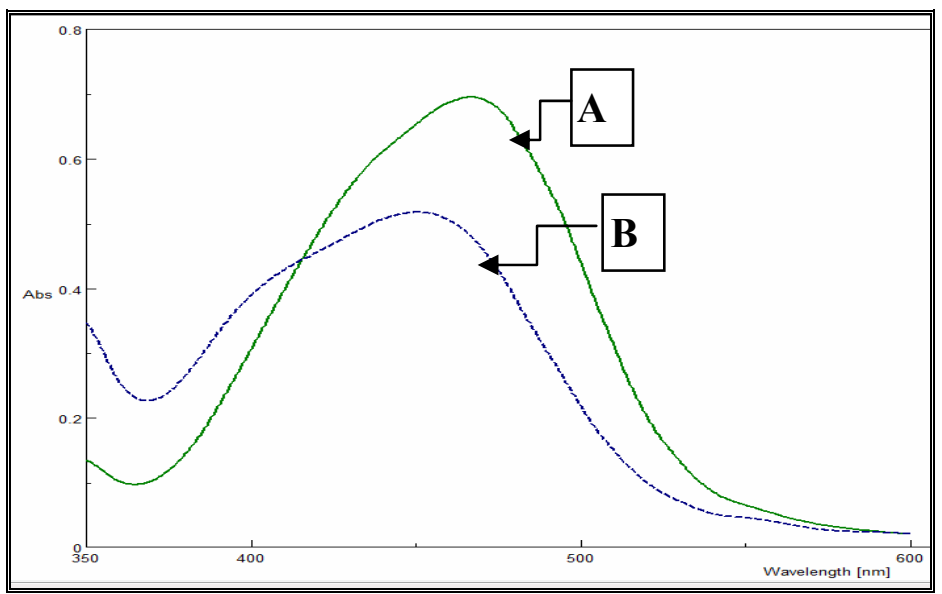

Fig. 1: The effect of Triton X-100 on absorbance (order II )

A-Sample with Triton $\mathrm{X}-10$

B- Sample without Triton X-100

The results in Table (5) and (Fig. 1) indicate that the addition of Triton X-100 in order (II) increases the intensity of the formed dye and color contrast from $141.5 \mathrm{~nm}$ To $158 \mathrm{~nm}$, therefore it has been recommended in subsequent experiments. 
The optimum amount of Triton $\mathrm{X}-100$

From the results in Table (6), it was found that $1 \mathrm{ml}$ of (1\%) TritonX-100 solution was adequate for the maximum absorbance, therefore it has been used in the subsequent experiments.

Table 6: The effect of TritonX-100 amount on absorbance

\begin{tabular}{|c|c|c|c|c|}
\hline ml of (1\%) TritonX-100 & $\mathbf{0 . 5}$ & $\mathbf{1 . 0}$ & $\mathbf{2 . 0}$ & $\mathbf{3 . 0}$ \\
\hline Absorbance & 0.6756 & 0.6913 & 0.6715 & 0.6710 \\
\hline
\end{tabular}

\section{Effect of time and amount of salbutamol sulphate on absorbance}

A study of the time effect on color development showed that the color formed immediately and remained stable for at least 90 minutes, Table (7).

Table 7: Stability of azo dye

\begin{tabular}{|c|c|c|c|}
\hline \multirow{2}{*}{ Time/min. } & \multicolumn{3}{|c|}{ Absorbance/ $\boldsymbol{\mu g}$ of Salbutamol sulphate present } \\
\cline { 2 - 4 } & $\mathbf{5 0}$ & $\mathbf{1 0 0}$ & $\mathbf{2 0 0}$ \\
\hline After dilution & 0.3678 & 0.7061 & 1.3129 \\
\hline 10 & 0.3652 & 0.6903 & 1.2981 \\
\hline 20 & 0.3636 & 0.6933 & 1.2939 \\
\hline 30 & 0.3670 & 0.6964 & 1.2940 \\
\hline 40 & 0.3727 & 0.6916 & 1.2958 \\
\hline 50 & 0.3721 & 0.6946 & 1.2906 \\
\hline 60 & 0.3752 & 0.6949 & 1.2969 \\
\hline 90 & 0.3754 & 0.6962 & 1.2952 \\
\hline 120 & 0.3904 & 0.6821 & 1.2390 \\
\hline Over night & 0.1130 & 0.4103 & 0.9259 \\
\hline
\end{tabular}

\section{Final Absorption Spectra}

Absorption spectra of the colored dye formed from treatment salbutamol sulphate with diazotized 5-amino-2-chlorobenzotriflouride reagent in basic medium, in the presence of TritonX100 , according to the above recommended procedure, showed that the maximum absorption is obtained at $467 \mathrm{~nm}$ (Fig. 2).

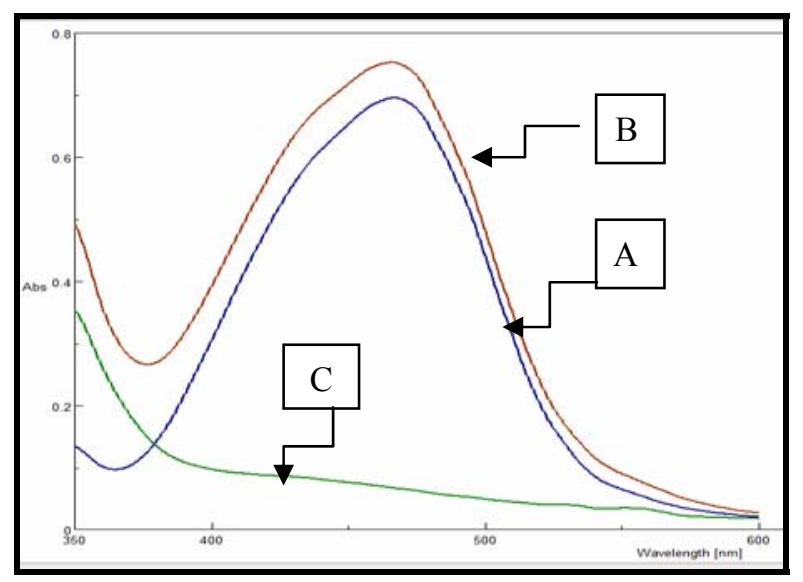

Fig. 2: Absorption spectra of $100 \mu \mathrm{g}$ salbutamol sulphate/10 ml treated according to the recommended procedure and measured against (A) blank, (B) distilled water and (C) blank measured against distilled water. 


\section{Procedure and calibration graph}

To a series of $10-\mathrm{ml}$ volumetric flasks, increasing volumes of aqueous solution containing 5-300 $\mu \mathrm{g}$ salbutamol sulphate are transferred, $4 \mathrm{ml}$ diazotized 5-amino-2-chlorobenzotrifluoride $\left(5 \times 10^{-3} \mathrm{M}\right)$ followed by the addition at $1 \mathrm{ml}$ of $(1 \%)$ Triton $\mathrm{X}-100$ and $1 \mathrm{ml} \mathrm{NaOH}(2 \mathrm{M})$ then the volumes were completed to the mark with distilled water. The absorbance for each flask was measured directly after dilution at $467 \mathrm{~nm}$ against blank. The calibration graph is linear over the range $0.5-30 \mu \mathrm{g} \cdot \mathrm{ml}^{-1}$ and higher concentrations show negative deviation from Beer's law (Fig. 3). The apparent molar absorptivity referred to salbutamol sulphate, has been found to be $4.2 \times 10^{4} 1 . \mathrm{ol}^{-1} \cdot \mathrm{cm}^{-1}$.

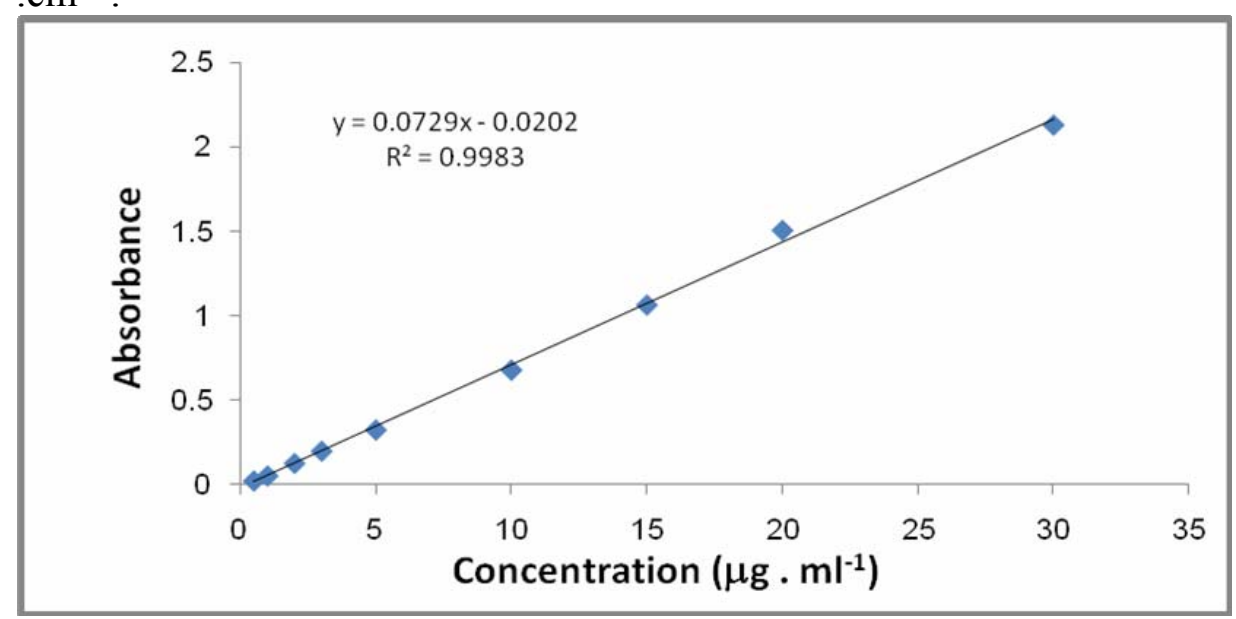

Fig. 3: Calibration graph for salbutamol sulphate determination using the proposed method

Nature of the dye

Continuous variations (Job's method) and mole - ratio methods (Delevie, 1997) indicate that the dye has a composition of 1:1 salbutamol sulphate [SBS] to diazotized 5-amino-2chlorobenzotriflouride [Diaz.] reagent (Fig. 4 and 5).

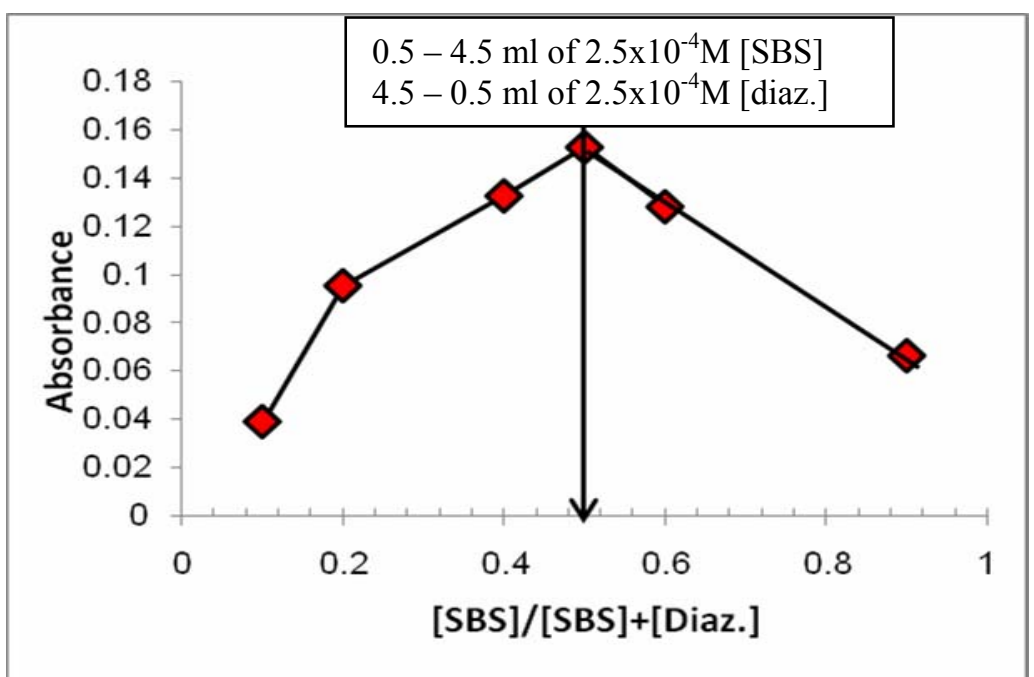

Fig. 4: Job`s method plot 


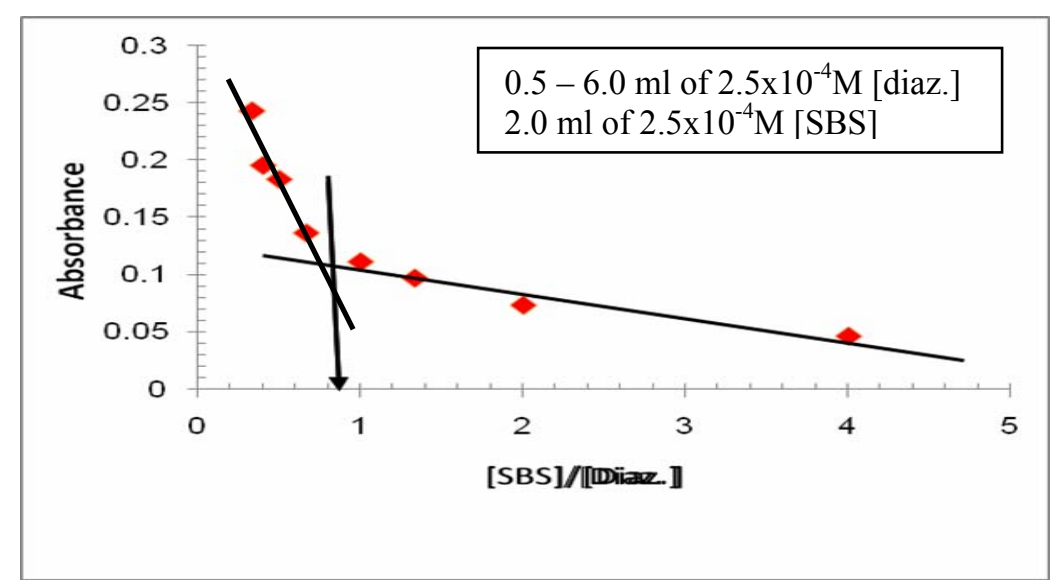

Fig. 5: Mole ratio method plot

Hence the dye may have the following structure.

\section{Interference}

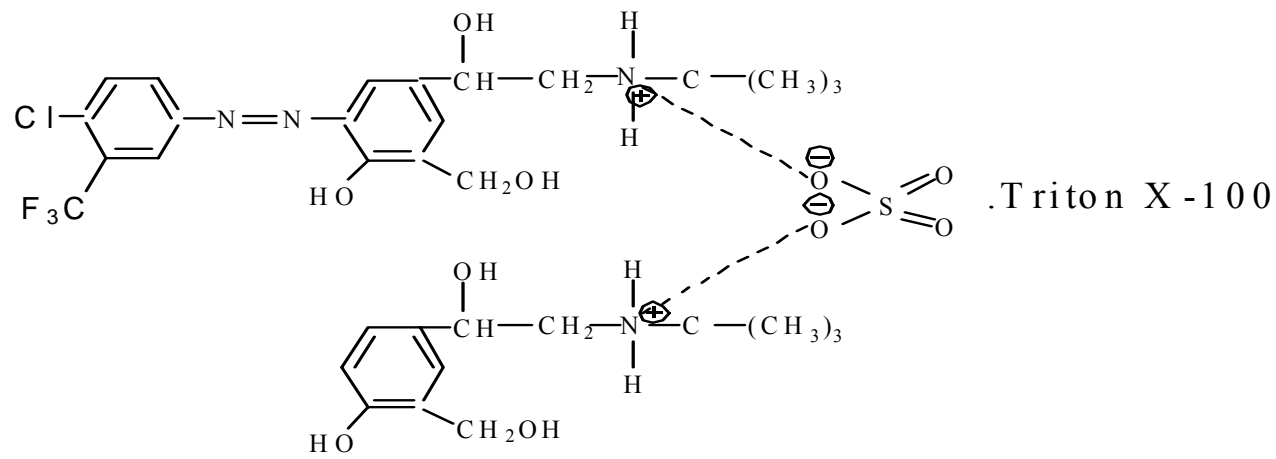

The extent of interferences by some excipients which often accompany pharmaceutical preparations as studied by measuring the absorbance of solutions containing $100 \mu \mathrm{g} \mathrm{ml} l^{-1}$ of salbutamol sulphate and various amounts (50,100 and1000) of exaplents in a final volume of $10 \mathrm{ml}$. It was found that the studied excipients do not interfere in the determination of salbutamol sulphate in its dosage forms. Typical results are given in Table (8).

Table 8: Effect of foreign compounds on the determination of $100 \mu \mathrm{g}$ salbutamol sulphate

\begin{tabular}{|c|c|c|c|}
\hline \multirow[t]{2}{*}{ Foreign compound } & \multicolumn{3}{|c|}{$\begin{array}{l}\text { Recovery (\%) of } 100 \mu \mathrm{g} \text { salbutamol sulphate per } \mu \mathrm{g} \text { foreign compound } \\
\text { added }\end{array}$} \\
\hline & 100 & 500 & 1000 \\
\hline Glucose & 98.36 & 99.86 & 97.21 \\
\hline Arabic Gum & 102.52 & 100.53 & 101.46 \\
\hline Lactose & 96.29 & 95.55 & 98.04 \\
\hline Starch & 101.19 & 97.95 & 101.97 \\
\hline
\end{tabular}

\section{Application of the method}

The proposed method was applied to determine salbutamol sulphate in its pharmaceutical preparations (Butadin syrup, tablet and Salbu. Vent.). The results shown in Table (9) indicated that a good recovery and the RSD $\%$ was better than $\pm 3.50 \%$. 
Table 9: Analytical applications of the proposed method

\begin{tabular}{|c|c|c|c|c|}
\hline Pharmaceutical preparation & $\begin{array}{c}\text { Amount } \\
\text { taken }(\boldsymbol{\mu g})\end{array}$ & $\begin{array}{c}\text { Amount measured } \\
(\boldsymbol{\mu g})\end{array}$ & Recovery,(\%*) & RSD,(\%*) \\
\hline \multirow{2}{*}{ 2 mg salbutamol sulphate/ 5 ml } \\
\cline { 2 - 5 } (S.D.I Iraq) & 50 & 51.72 & 103.44 & $3.17 \pm$ \\
\cline { 2 - 5 } & 100 & 101.08 & 101.08 & $0.76 \pm$ \\
\hline $\begin{array}{c}\text { Butadin tablet } \\
\text { 2 mg salbutamol sulphate/ tablet } \\
\text { (S.D.I Iraq) }\end{array}$ & 50 & 51.69 & 103.38 & $1.73 \pm$ \\
\cline { 2 - 5 } & 100 & 102.16 & 102.16 & $2.47 \pm$ \\
\hline $\begin{array}{c}\text { Salbu. Vent. } \\
\text { 5 mg salbutamol sulphate/ 1 ml } \\
\text { (Diamond pharma-syria) }\end{array}$ & 50 & 50.90 & 101.80 & $3.50 \pm$ \\
\cline { 2 - 5 } & 100 & 101.63 & 101.63 & $2.35 \pm$ \\
\hline
\end{tabular}

*Average of five determinations

The validity of the method was confirmed by applying the standard addition procedure (AlAbachi, and Al-Ghabsha, 1986) (Fig. 6).

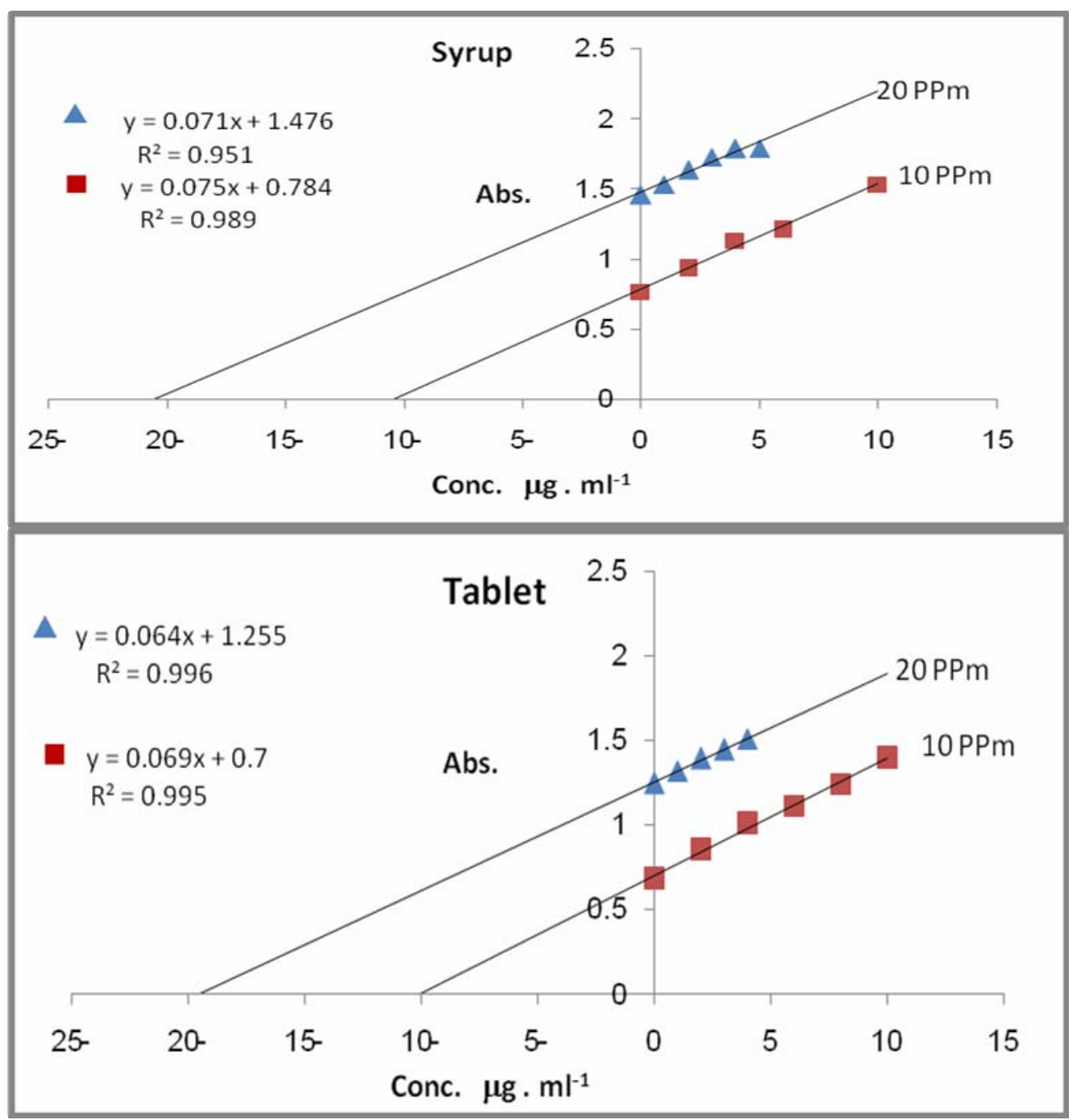




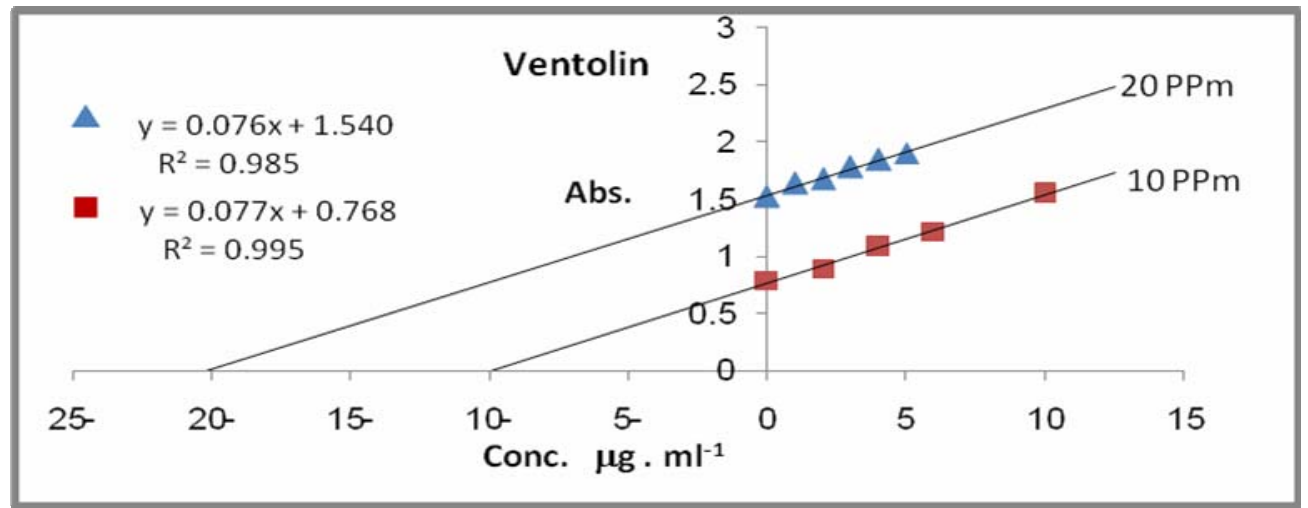

Fig. 6: Standard addition plot for the recoveries of $10,20 \mu \mathrm{g}$ of salbutamol sulphate in butadin syrup, tablet and ventolin respectively.

The recoveries calculated by using the equations of the linearity in (Fig. 6) and the results obtained are in agreement with the certified value Table (10).

Table 10: The results of standard addition method

\begin{tabular}{|c|c|c|c|}
\hline Pharmacetical preparation & $\begin{array}{l}\text { Amount taken } \\
\left(\mu \mathrm{g} . \mathrm{ml}^{-1}\right)\end{array}$ & $\begin{array}{l}\text { Amount measured } \\
\left(\mu \mathrm{g} \cdot \mathrm{ml}^{-1}\right)\end{array}$ & $\begin{array}{l}\text { Recovery, } \\
\%\end{array}$ \\
\hline \multirow{2}{*}{ 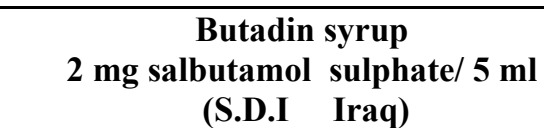 } & 10 & 10.45 & 104.50 \\
\hline & 20 & 20.78 & 103.90 \\
\hline \multirow{2}{*}{$\begin{array}{c}\text { Butadin tablet } 2 \text { mg salbutamol } \\
\text { sulphate/ tablet (S.D.I Iraq) }\end{array}$} & 10 & 10.14 & 101.40 \\
\hline & 20 & 19.61 & 98.05 \\
\hline \multirow{2}{*}{$\begin{array}{c}\text { Salbu. Vent. } \\
5 \text { mg salbutamol sulphate/ } 1 \mathrm{ml} \\
\text { (Diamond pharma-syria) }\end{array}$} & 10 & 9.97 & 99.70 \\
\hline & 20 & 20.26 & 101.30 \\
\hline
\end{tabular}

\section{Comparison of the methods}

Table (11) shows the comparison between some of analytical variables obtained from the present method with other spectrophotometric methods.

Table 11: Comparison of the methods

\begin{tabular}{|c|c|c|c|c|}
\hline Parameter & Present method & $\begin{array}{c}\text { Othman and } \\
\text { Zakaria , 2004 }\end{array}$ & $\begin{array}{c}\text { Othman and } \\
\text { Hamdoun, 2005 }\end{array}$ & $\begin{array}{l}\text { Al-Hafith } \\
\text { (2005) }\end{array}$ \\
\hline Reagent & $\begin{array}{l}\text { Diazotized 5-amino-2- } \\
\text { chlorobenzotriflour-ide }\end{array}$ & $\begin{array}{c}\text { Diazotized } \\
\text { sulphanilic acid }\end{array}$ & $\begin{array}{l}\text { Diazotized p- } \\
\text { nitroaniline }\end{array}$ & $\begin{array}{l}\text { p-Phenylenedi-amine in } \\
\text { presence of meta per } \\
\text { iodate }\end{array}$ \\
\hline pH & 12.01 & - & 12.2 & 9 \\
\hline Temperature $\left(C^{0}\right)$ & R.T. & R.T. & R.T. & R.T. \\
\hline $\begin{array}{l}\text { Development time } \\
\text { (min.) }\end{array}$ & After dilution & 10 & After dilution & 50 \\
\hline$\lambda_{\max }(\mathrm{nm})$ & 467 & 445 & 488 & 552 \\
\hline $\begin{array}{c}\text { Beer's law range } \\
(\mathrm{ppm})\end{array}$ & $0.5-30$ & $0.8-4.0$ & $0.4-4.8$ & $0.8-40$ \\
\hline $\begin{array}{c}\text { Molar absorptivity } \\
\left(1 . \mathrm{mol}^{-1} \cdot \mathrm{cm}^{-1}\right)\end{array}$ & $4.15 \times 10^{4}$ & $3.53 \times 10^{4}$ & $3.13 \times 10^{4}$ & $2.30 \times 10^{4}$ \\
\hline Colour of the dye & Yellow - orange & Yellow & Orange & Violet \\
\hline $\begin{array}{c}\text { Application of the } \\
\text { method }\end{array}$ & $\begin{array}{l}\text { Syrup, tablet and } \\
\text { ventoline }\end{array}$ & Syrup and tablet & Syrup and tablet & $\begin{array}{l}\text { Syrup, tablet and } \\
\text { ventoline }\end{array}$ \\
\hline
\end{tabular}




\section{CONCLUSION}

The advantage of the proposed method compared to the reference methods was a higher sensitivity than the refered methods which were linear from 0.5-30 $\mu \mathrm{g} \cdot \mathrm{ml}^{-1}$. Moreover, the proposed method could be applied successfully to the determination of the salbutamol sulphate in a pure form as well as in its dosage forms.

\section{REFERENCES}

Al-Abachi, M.Q.; Al-Ghabsha, T.S. (1986). "Fundamentals of Analytical Chemistry". Mosul University Press, p.197 (in Arabic).

Al-Abachi, M.Q.; Subhi, S. (2013). Flow injection- spectrophotometric determination of salbutamol sulphate and pyridoxine hydrochloride using 2,4- dinitrophenylhydrazine. Iraqi J. Sci., 54(1), 6-16.

Al-Hafith, H.A. (2005). Development of spectrophotometric methods for the determination of some phenolic compounds and catecholamines in pharmaceutical preparations. M.Sc. Thesis, Mosul University, $45 \mathrm{p}$.

Attaran, M.A.; Javanbakht, M.; Fathollahi, F.; Enhessari, M. (2012). Determination of salbutamol in pharmaceutical and serum samples by adsorptive stripping voltammetry on a carbon paste electrode modified by iron titanatenano powders. Electroanal., 24 (10), 2013-2020.

Bao, Y.; Yang, F.; Yang, X. (2012). Capillary electrophoresis coupled with electrochemiluminescence for the facile separation and determination of salbutamol and clenbuterol in urine. Electroanal., 24(7),1597-1603.

Basavaiah, K.; Prameela, H.C. (2003). Spectrophotometric determination of salbutamol sulfate and pyrantel pamoate in bulk drugs and pharmaceuticals. Chem. Anal., 48(2), 327-334.

British Pharmacopoeia on CD-ROM, (2007). Copyright by System Simulation Ltd. The Stationery Office Ltd., London.

Caban, M.; Stepnowski, P.; Kwiatkowski, M.; Migowska, N. (2011). Determination of b-blockers and b-agonists using gas chromatography and gas chromatography-mass spectrometry - A comparative study of the derivatization step. J. Chromatogr. A. 1218(44), 8110-8122.

Dave, H.N.; Mashru, R.C.; Patel, A.K. (2011). Thin Layer chromatography method for the determination of ternary mixture containing salbutamol sulphate, bromhexine hydrochloride and etofylline. J. Pharma. Sci. Res., 2(3), 143-148 .

Delevie, R. (1997)." Principles of Quantitative Chemical Analysis". McGraw-Hill, International Edn., Singapore, p.498.

Eswarudu, M.M.; Sushma, M.; Sushmitha, M.; Yamini, K. (2012). Validated spectrophotmetric method for the determination of salbutamol sulphate in bulk and pharmaceutical dosage forms. Int. Res. J. Pharma., 3(4), 423-425.

Fattah, E.; Grant, D.; Gabr, K. ; Meshali, M. (1998). Physical characteristics and release behaviour of salbutamol sulphate beads prepared with different ionic poly-saccharides. Drug Devel. Indust. Pharma., 24(6), 541 - 547.

Ganjali, M.R.; Norouzi, P.; Ghorbani, M.; Sepehri C.R. (2005). A fourier transform cyclic voltammetric technique for monitoring ultratrace amounts of salbutamol at gold ultra microelectrode in flowing solutions Talanta, 66(5), 1225-1233.

Ghulam, M.; Mahmood, A.; Muhammad, A.; Muhammad, W. (2009). A new reverse phase HPLC method with fluorescent detection for the determination of salbutamol sulphate in human plasma. Bull. Chem. Soc. Ethiopia, 23(1), 1-6.

Kanakapura, I.; Huiikal, C. (2003). Spectrophotometric determination of salbutamol sulphate and acyclovir using iron(III) and ferricyanide., Sci. Asia, 29,141-146.

Li, C.; Wu, Y.L.; Yang, T.; Zhang, Y. (2010). Simultaneous determination of clenbuterol, salbutamol and ractopamine in milk by reversed-phase liquid chromatography tandem mass spectrometry with isotope dilution. J. Chromatogr. A, 1217(50), 7873-7877 . 
Liu, C.; Wang, L. (2011). Research on determination of clenbuterol and salbutamol in pork by SPE-HPLC. Inter. Conf. New Technol. Agr., 1024-1026.

Manasa, A. (2013). Spectrophotometric determination of salbutamol sulphate in bulk form and in various dosage forms. The Experiment, 7(4), 445-449.

Mohamed, G.G.; Khalil, S.M.; Zayed, M.A.; El-Shall, M.A. (2002). 2,6-Dichloroquinone chlorimide and 7,7,8,8- tetracyanoquinodimethane reagents for the spectrophotometric determination of salbutamol in pure and dosage forms. J. Pharma. Biomed. Anal., 28(6), 1127-1133.

Mukesh, M.; Ranjit, S. (2011). Development and validation of a stability- indicating HPLC method for the simultaneous determination of salbutamol sulphate and theophylline in pharmaceutical dosage forms. J. Anal. Bioanal. Tech., 2(1),1-5.

Othman, N.S.; Hamdoun, E.A. (2005). Diazotized p-nitroaniline reagent for the determination of trace amount of salbutamol sulphate in aqueous solution-application to pharmaceutical preparation. Raf. J. Sci., 16,60-67.

Othman, N.S.; Zakaria, R.Z. (2004). Use of diazotized sulphanilic acid reagent in the spectrophotometric determination of salbutamol sulphate-application to pharmaceutical preparation. J. Edu. Sci., 16, 27-37.

Pai, P.N.; Rao, G.; Murthy, M.; Agarwal, A. (2009). Simultaneous determination of salbutamol sulphate and bromhexine hydrochloride in tablets by reverse phase liquid chromatography. Indian J. Pharma. Sci., 71(1), 53-55.

Tang, J.; Liu, Z.; Kang, J.; Zhang, Y. (2010). Determination of salbutamol using R-phycoerythrin immobilized on egg shell membrane surface as a fluorescence probe. Anal. Bioanal. Chem., 397(7), 3015- 3022.

Wang, L.; Li, Yuan-Q.; Zhou, Yun-K.; Yang, Y. (2010). Determination of four $\beta 2$-agonists in meat, liver and kidney by GC-Mass with dualinternal standards. Chromatographia ,71(7), 737-739.

Yan, H.; Wang, R.; Han, Y.; Liu, S. (2012). Screening, recognition and quantization of salbutamol residues in ham sausages by molecularly imprinted solid phase extraction coupled with highperformance liquid chromatography-ultraviolet detection. J. Chromatogr. B, 900, 18-23.

Zhang, Y.; Zhang, Z.; Sun, Y.; Wei, Y. (2011). Development of an analytical method for the determination of $\beta_{2}$-agonist residues in animal issues by high-performance liquid chromatography with on-line electrogenerated $\left[\mathrm{Cu}\left(\mathrm{hio}_{6}\right)_{2}\right]^{5-}$ luminol chemiluminescence detection. J. Agr. Food Chem., 55(13), 4949-4956. 